\title{
Ochronotic Arthropathy: A Report of Two Cases
}

\author{
(1) Selma Şengiz Erhan, ${ }^{1}$ (1) Sevinç Hallaç Keser, ${ }^{2}$ \\ [1 Kubilay Gülsever, ${ }^{3}$ 도 Sibel Sensu ${ }^{4}$
}

\section{'Department of Pathology, University of Health Sciences, Okmeydanı Training and Research Hospital, İstanbul, Turkey ${ }^{2}$ Department of Pathology, University of Health Sciences, Dr. Lutfi Kırdar Kartal Training and Research Hospital, İstanbul, Turkey ${ }^{3}$ Department of Orthopedics and Traumatology, Gebze State Hospital, Kocaeli, Turkey ${ }^{4}$ Department of Pathology, İstinye University Faculty of Medicine, İstanbul, Turkey \\ Submitted: 09.02.2019 Accepted: 22.07.2019 \\ Correspondence: Selma Şengiz Erhan, Okmeydanı Eğitim ve Araştırma Hastanesi, Sağlık Bilimler \\ Üniversitesi, Patoloji Bölümü İstanbul, Turkey \\ E-mail: selmaserhan@hotmail.com

Keywords: Degenerative
arthritis; hip joint;
knee joint; ochronotic
arthropathy; pigmentation.
Attribution-NonCommercial 4.0 International License.

\begin{abstract}
Ochronosis is an entity characterized by deposition of homogentisic acid and metabolites in connective tissues, such as joint cartilage, skin and sclera. Ochronosis is generally diagnosed by a clinical triad of degenerative arthritis, ochronotic pigmentation and urine color turning black upon alkalization. Since ochronotic arthropathy is one of the most important morbidity causes in ochronosis, in this study, we aimed to present two cases diagnosed. One of two cases we present had advanced degenerative alterations in both hip and knee, and the other case had advanced degenerative alterations in knee joints. Macroscopical examination of the resection materials revealed black pigmentation on joint surfaces. Histopathologically, cartilage lacunes filled with brown pigment and inflammatory infiltration, as well as brown pigmentation in soft tissue, were observed. Clinical history revealed that the patients had dark urine since childhood and they detected dark spotting at their underwear. As all findings evaluated together, these two rare cases, which are diagnosed as ochronotic arthropathy, reviewed in the light of the literature.
\end{abstract}

\section{INTRODUCTION}

Alkaptonuria is a rare hereditary disorder of tyrosine and phenylalanine metabolism occurring approximately one in I million people. ${ }^{[1,2]}$ Alkaptonuria is characterized by an increase in level and urinary excretion of homogentisic acid (HGA) due to hereditary deficiency of homogentisic acid oxidase (HGO) that has a role in the metabolism of this amino acid. ${ }^{[1,3,4]}$ Ochronosis is the deposition of HGA and metabolites in connective tissues, such as eye, ear cartilage, skin, buccal mucosa and tendons leading to dark pigmentation. ${ }^{[5,6]}$ In addition to the pigmentation of connective tissues, genitourinary, cardiovascular and respiratory symptoms are also described. The most important morbidities are ochronotic arthropathy and cardiovascular involvement. ${ }^{[7,8]}$ It is mostly diagnosed with a clinical triad of the dark color of urine upon alkalization (alkaptonuria), ochronotic pigmentation (ochronosis) and degenerative, progressive arthritis (ochronotic arthropathy)..$^{9,10]}$ No specific therapy is available and generally, only symptomatic therapy is administered for complications. ${ }^{[6,10,11]}$

\section{CASE REPORT}

Case I- A 62-year-old male admitted to Orthopedics \& Traumatology Clinic due to difficulty in walking short distances as well as pain in both knees and right hip. He had movement restriction in both knees and hip (right hip abduction 40 and flexion 60) and movements were painful. In left lateral knee radiography, advanced arthrosis and periarticular calcifications were seen in the knee joint (Fig. la). In anteroposterior (AP) pelvic radiography, there was grade 4 osteonecrosis in right hip, narrowing of sacroiliac 
joints and osteophyte formations at joints (Fig. Ib). The patient was hospitalized for knee arthroplasty operation with diagnoses of gonarthrosis and coxarthrosis. Level of red blood cells was $3.24 \times 10^{6} / \mathrm{mm}^{3}\left(4.2-5.5 \times 10^{6} / \mathrm{mm}^{3}\right)$, hemoglobin $(\mathrm{Hb})$ level was $9.7 \mathrm{~g} / \mathrm{dL}(11.7-16 \mathrm{~g} / \mathrm{dL})$, and hematocrit (Hct) level was $28.1 \%$ (35-47\%); all were lower than normal values. The sedimentation rate was $17 \mathrm{~mm} / \mathrm{hr}$. During the operation, besides advanced stage 4 gonarthrosis, a dark pigmentation was seen in femur condyles, meniscuses, tibia plateau and patellar condyles of both knees (Fig. 2). Three months later, the patient was operated for coxarthrosis, and the femoral head extracted during the procedure also had a dark pigmentation. Bone fragments from the right and left knee and also the joint surface of the resection material, including femoral head, showed black pigmentation.

Case 2- A 64-year-old female patient with deformation on left knee admitted to Orthopedics \& Traumatology Clinic due to difficulty in walking long distance and knee pain aggravating for the last 5-6 months. Fatigue, fever and weight loss were not present, and any pathological finding was not found in the systemic examination. Radiological images of the case were not available. She was hospitalized for knee arthroplasty operation for gonarthrosis on the left knee joint. Red blood cell count was $3.12 \times 10^{6} / \mathrm{mm}^{3}\left(4.2-5.5 \times 10^{6} /\right.$ $\left.\mathrm{mm}^{3}\right), \mathrm{Hb}$ level was $9 \mathrm{~g} / \mathrm{dL}(1 \mathrm{l} .7-16 \mathrm{~g} / \mathrm{dL})$ and $\mathrm{Hct}$ level was
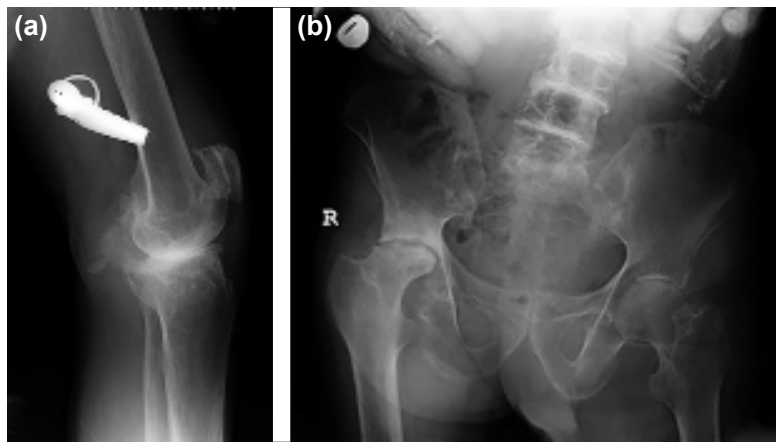

Figure 1. (a) Advanced arthrosis and periarticular calcifications in left lateral knee joint radiography, (b) Grade 4 osteonecrosis, narrowing at sacroiliac joint and osteophytic formations at joints, in right pelvis at AP pelvicradiography.

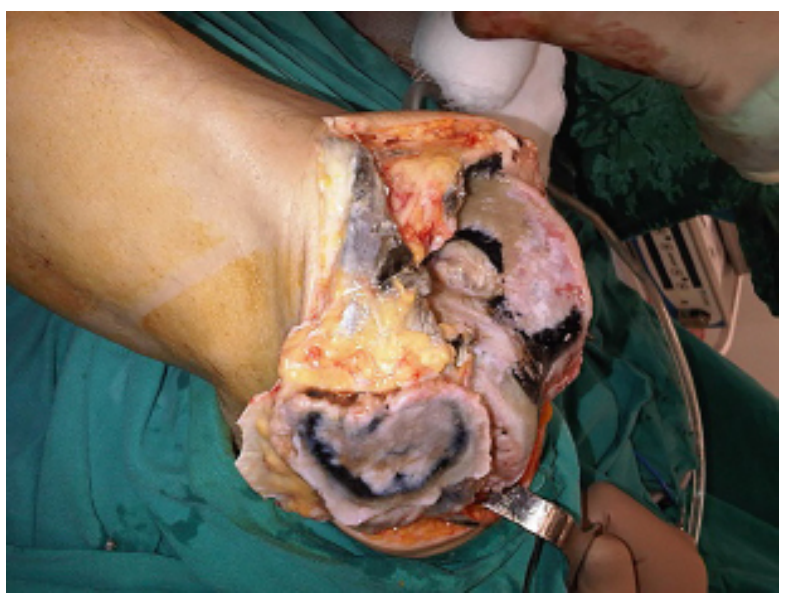

Figure 2. Knee joint with black foci and degenerative alterations.
$28.5 \%$ (35-47\%); all were lower than normal. Sedimentation was $40 \mathrm{~mm} / \mathrm{hr}$. Urine analysis revealed no abnormal finding. During operation, black color was observed on meniscuses and extracted bone fragments. Macroscopic examination of the material that included bone and soft tissue fragments had black pigmentation on joint surfaces.

In the microscopical examination of both tissues, cartilage lacunes stained with brown pigment, brown pigment deposits in soft tissue, focal lymphocyte and plasma cell infiltration and cartilage tissue fragments with foreign body giant cells and brown pigmentation were observed (Figs. 3, 4). All the
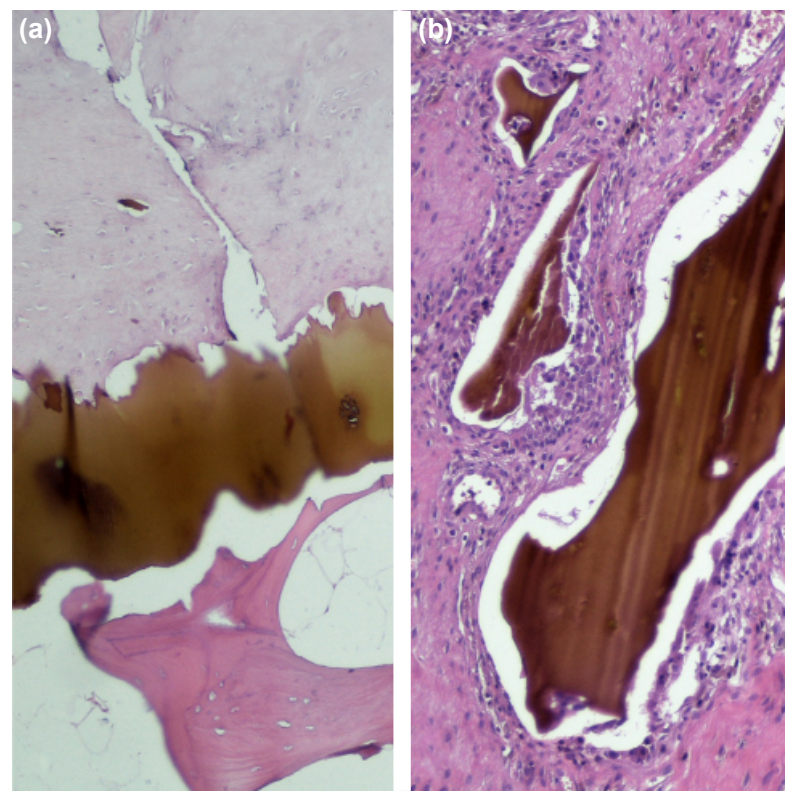

Figure 3. (a) Brown pigmentation deposits in the cartilage of joint (H\&E, x40), (b) Cartilage tissue fragmants with foreign giant cells (H\&E, $x 200)$.
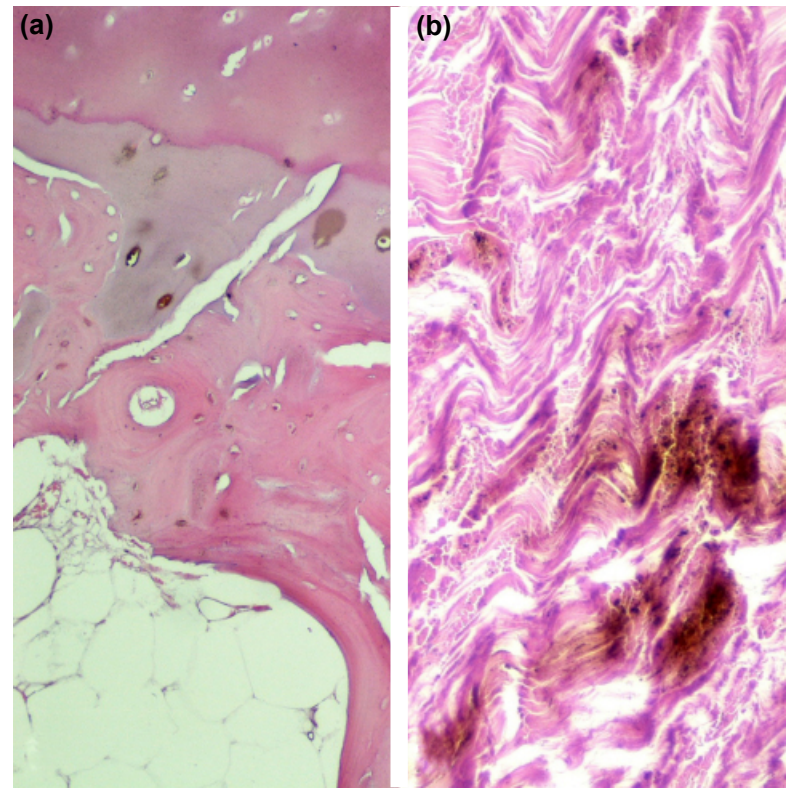

Figure 4. (a) Cartilage lacunes with brown pigment (H\&E, x40), (b) Brown pigmentation in soft tissue (H\&E, x100). 
findings were more prominent in Case 2. However, bone trabeculae were slightly thinner in Case I. Reexamination of the patients revealed that the urine was dark since childhood, and underwear used to have prominent black spots. In patients' history, drug use, the occupational disease that might cause high metal poisoning or a clue for exogenous ochronosis were not present. When histopathological and clinical findings were collectively analyzed, the cases were diagnosed as ochronotic arthropathy.

During the follow up of cases, no complication was observed. However, the patients discontinued coming to control visits (Case I, after three months and Case 2, after five months) and further follow-up was terminated.

\section{DISCUSSION}

Ochronosis, which has an autosomal recessive transmission and is observed twice more at men than women, is generally asymptomatic till adulthood..$^{[3,6]}$

In early ages, infant diaper turning gray-black or staining black upon contact with an alkaline material, such as soap, may be the sign. ${ }^{[10,12]}$ In the clinical history of both of our cases, the patients mentioned their underwear turning black upon contact with urine.

The deposition of ochronotic pigment in connective tissues is first seen during the 3rd-4th decade. Gray-blue pigmentation in the tendon, ligament, sclera, ear cartilage, heart valves, intima of blood vessels, tooth, fingernail and dura mater is observed. ${ }^{[6,9,13]}$ Inflammation, degeneration and pigmentation occur in affected tissues and the tissue becomes weaker and more fragile. ${ }^{[10,14]}$ In neither of our cases, pigment deposition in connective tissues was found in the systemic examination.

Clinical signs and symptoms occur in the $4^{\text {th }}-5^{\text {th }}$ decade. Urine color turning black upon alkalinization, the ochronotic pigment in tissues and degenerative arthritis make the classical triad that leads to the diagnosis. ${ }^{[8,9]}$ Qualitative HGA detection in urine is also diagnostic. ${ }^{[15]}$ Due to ochronotic pigment deposition, joint capsule, tendon and ligaments become dark brown-black. In the advanced stage, erosion and progressive degenerative alterations are seen at cartilage. ${ }^{[10]}$ Ochronotic pigment deposition might be observed in two ways, which are ochronotic spondylosis and peripheral arthropathy. ${ }^{[3,16]}$ In peripheral arthropathy, mostly knee, shoulder and hip and rarely, small joints of hand and foot, wrist, elbow and ankle are affected. ${ }^{[17]}$

In most cases, diagnosis is made by chance in patients that are operated because of orthopedic complaints. Degenerative alterations and striking color changes analyzed in collaboration with histopathology lead to the diagnosis. $[8,10]$ Histologically, depending on the amount of HGA deposition in synovial tissue, joint cartilage fragments with brown-black pigmentation, and surrounding granulation tissue with foreign body giant cells, slight lymphocyte and plasma cell inflammatory infiltration are observed. ${ }^{[8,16]}$ The pigment is not deposited in bone tissue, but calcification and bone remodelling might be seen. Bone findings are usually less severe than cartilage and are not related to disease progression. ${ }^{[18,19]}$

In clinical differential diagnosis, osteoarthritis, ankylosing spondylitis and rheumatoid arthritis should be considered. Correlation of laboratory and radiological data with clinical findings would be valuable for differentiation. ${ }^{[9,12]}$

Clinical course and prognosis of the disease depend on the severity of alkaptonuria. Some cases might show a benign course with minimal joint involvement. However, in some cases, there is an aggressive clinical course with cardiac insufficiency or progressive spinal deformity as well as the involvement of knee, hip and shoulder joints. ${ }^{[3,6,8]}$

In ochronosis, although severe morbidity, such as ochronotic arthropathy and cardiovascular involvement, does not affect survival, they decrease quality of life since they lead to progressive disability. ${ }^{[7,8]}$

Clinical history, in our cases, shows that disease signs actually begin during the neonatal period, but patients and caregivers disregard the signs. Thus, patients may present years later with delayed diagnosis and symptoms that affect their quality of life. We present these cases, which should be considered in the differential diagnosis of degenerative joint diseases, to emphasize the significance of early diagnosis and proper treatment.

\section{Informed Consent}

Written informed consent was obtained from the patient for the publication of the case report and the accompanying images.

Peer-review

\section{Internally peer-reviewed.}

Authorship Contributions

Concept: S.Ş.E., S.H.K.; Design: S.Ş.E., S.H.K.; Data: S.Ş.E., K.G.; Analysis: S.Ş.E., S.H.K., S.S.; Literature search: S.Ş.E., K.G.; Writing: S.Ş.E., S.H.K., S.S.; Critical revision: K.G., S.H.K., S.S.

\section{Conflict of Interest}

None declared.

\section{REFERENCES}

1. Garrod AE. About alkaptonuria. Lancet 1901;2:69-78. [CrossRef]

2. Kraus WB. Rare osteoarthritis: ochronosis and Kashin-beck disease. In: Hochberg MC, Silman AJ, Smolen JS, Weinblatt ME, Weisman MH, editors. Rheumatology. 6th ed. Philadelphia: Elsevier; 2015. p. 1536-49.

3. Laskar FH, Sargison KD. Ochronotic arthropathy: A review with four case reports. J Bone Joint Surg Br 1970;52:653-66. [CrossRef]

4. Phornphutkul C, Introne WJ, Perry MB, Bernardini I, Murphey MD, Fitzpatrick DL, et al. Natural history of alkaptonuria. N Engl J Med 2002;347:2111-21. [CrossRef]

5. Taylor AM, Wlodarski B, Prior IA, Wilson PJ, Jarvis JC, Ranganath LR, et al. Ultrastructural examination of tissue in a patient with alkaptonuric arthropathy reveals a distinct pattern of binding of ochronotic pigment. Rheumatology (Oxford) 2010;49:1412-4.

6. Gil JA, Wawrzynski J, Waryasz GR. Orthopedic manifestations of 
ocrhronosis: Pathophysiology, presentation, diagnosis, and management. Am J Med 2016;129:536.e1-6. [CrossRef]

7. Erek E, Casselman FR, Vanermen H. Cardiac ochronosis: Valvular heart disease with dark green discoloration of the leaflets. Tex Heart Inst J 2004;31:445-7. [CrossRef]

8. Millucci L, Bernardini G, Spreafico A, Orlandini M, Braconi D, Laschi M, et al. Histological and Ultrastructural Characterization of Alkaptonuric Tissues. Calcif Tissue Int 2017;101:50-64. [CrossRef]

9. Groseanu L, Marinescu R, Laptoiun D, Botezatu I, Staniceanu F, Zu$\operatorname{rac} \mathrm{S}$, et al. A late and difficult diagnosis of ochronosis. J Med Life 2010;3:437-43.

10. Doganavsargil B, Pehlivanoglu B, Bicer EK, Argin M, Bingul KB, Sezak M, et al. Black joint and synovia: Histopathological evaluation of degenerative joint disease due to Ochronosis. Pathol Res Pract 2015;211:470-7. [CrossRef]

11. Spencer JM, Gibbons CL, Sharp RJ, Carr AJ, Athanasou NA. Arthroplasty for ochronotic arthritis: no failure of 11 replacements in 3 patients followed 6-12 years. Acta Orthop Scand 2004;75:355-8.

12. Rathore FA, Ayaz SB, Mansoor SN. Ochronotic Arthropathy: Two Case Reports from a Developing Country. Clin Med Insights Arthri- tis Musculoskelet Disord 2016;9:15-20. [CrossRef]

13. Aytuğ AF, Gürbüz O, Ergun T, Kotiloğlu E. Endojen okronozis: Bir alkaptonuri olgusu. TURKDERM 2002;36:276-9.

14. Keller JM, Macaulay W, Nercessian OA, Jaffe IA. New developments in ochronosis: review of the literature. Rheumatol Int 2005;25:81-5.

15. Tietz NW. Clinical guide to laboratory tests. 5 th ed. Wb Saunders Company; 2005.

16. Helliwell TR, Gallagher JA, Ranganath L. Alkaptonuria--a review of surgical and autopsy pathology. Histopathology 2008;53:503-12.

17. Wold LE, Unni KK, Sim FH, Sundaram M, Adler C. OchronosisDisorder of tyrosine and phenylalanine catabolism secondary to homogentisic acid and related compounds. In: Schmitt W, editor. Atlas of orthopedic pathology. 3rd ed. Philadelphia: Saunders Elsevier; 2008. p. 121-4. [CrossRef]

18. Aliberti G, Pulignano I, Schiappoli A, Minisola S, Romagnoli E, Proietta M. Bone metabolism in ochronotic patients. J Intern Med 2003;254:296-300. [CrossRef]

19. Di Franco M, Coari G, Bonucci E. A morphological study of bone and articular cartilage in ochronosis. Virchows Arch 2000;436:74-81.

\section{Okronotik Artropati: Iki Olgu Sunumu}

Okronozis homogentisik asit ve metabolitlerinin eklem kıkırdağı, deri ve sklera gibi konnektif dokularda birikimiyle karakterize bir tablodur. Tanı genellikle dejeneratif artrit, okronotik pigmentasyon ve idrar renginin alkalizasyonu sonucu siyahlaşmasından oluşan klinik triad ile konur. Okronozisde en önemli morbidite nedenlerinden biri okronotik artropati olduğu için, tanı alan iki olguyu sunmayı amaçladık. Olgulardan birinin kalça ve diz, diğerinin diz eklemlerinde ileri derecede dejeneratif değişiklikler mevcuttu. Operasyon materyallerinin makroskopik incelemesinde eklem yüzeylerinde siyah renk değişikliği dikkati çekti. Histopatolojik incelemede; kahverenkli pigment içeren kıkırdak lakünleri, yumuşak dokuda inflamatuar infiltrat ile birlikte kahverenkli pigment birikimi gözlendi. Klinik öyküleri sorgulandığında; küçüklüklerinden beri idrarlarının koyu renkli olduğu ve iç çamaşırlarına idrar teması sonucunda siyah renkte leke oluştuğu ifade edildi. Tüm bulgular birlikte değerlendirildiğinde okronotik artropati tanısı alan iki olgu nadir görülmeleri nedeniyle literatür verileri eşliğinde gözden geçirildi.

Anahtar Sözcükler: Dejeneratif artrit; diz eklemi; kalça eklemi; okronotik artropati; pigmentasyon. 